\title{
ASSOCIATION BETWEEN DIFFERENT BLOOD GROUPS, DEPRESSION AND ORAL HEALTH STATUS OF DENTAL STUDENTS
}

\author{
KALURAM YADAV ${ }^{1}$, JITENDER SOLANKI ${ }^{1}$, C. L. DILEEP ${ }^{1}$, \\ B. R. ADYANTHAYA ${ }^{2}$, PRASHANT MISHRA ${ }^{3}$, OMPRAKASH YADAV ${ }^{1}$
}

\author{
${ }^{1}$ Public Health Dentistry Department, Rajasthan Dental College and Hospital, \\ Jaipur, India \\ ${ }^{2}$ Department of Endodontics and conservative, Rajasthan Dental College and \\ Hospital, Jaipur, India \\ ${ }^{3}$ Department of Public Health Dentistry, Shri Aurobindo College of Dentistry, \\ Indore
}

\section{Abstract}

Introduction. Knowledge of blood groups and their association with oral diseases and depression is very important, as it may help in early diagnosis and treatment strategies.

Method. A cross sectional descriptive study was conducted among dental students of a private dental college. The study was conducted in two phases, in the first phase the blood samples of each student were collected and sent for blood group examination in laboratory. Data for oral health status was collected by recording oral hygiene, dental caries and questions regarding oral hygiene habits and adverse oral habits. Depression level was recorded using a pre-validated, 21 item close ended questionnaire. Data thus collected was subjected to statistical analysis using chisquare and frequency distribution test using SPSS software.

Results. The total study subjects were 315, 95 males and 220 females. On applying chi-square test between blood group and Decayed, Missing and Filled Teeth (DMFT) score, a highly significant association $(p=0.00)$ was observed. Anon-significant association $p=0.217$ and $p=0.668$ was observed between gender and DMFT and Oral hygiene index-simplified and Blood group respectively. When comparing blood group and Depression score, a non-significant association $(p=0.74)$ was observed.

Conclusion. DMFT score varies in different blood groups and this might suggest a positive association between blood groups and DMFT score, while depression, oral hygiene and gender might not be affected by the different blood groups.

Keywords: blood group, dental caries, depression, DMFT, oral hygiene, periodontal disease

\section{Introduction}

It is well known that dental diseases can vary with respect to bacterial etiology, host response, and clinical disease progression. Although there is a difference between periodontal disease and dental caries, both share the common characteristic of complex host-bacterial interactions [1]. Bacteria are the main cause of infection and there is increasing evidence that host factors, such as diet, diabetes, smoking and genetic predispositions contribute to the clinical appearance. It has been estimated that less than $20 \%$ of the variability in

Manuscript received: 28.06.2017

Received in revised form: 23.11.2017

Accepted: 17.01.2018

Address for correspondence: kaluram1688@gmail.com periodontal disease severity can be explained by the quantity of specific bacteria found in disease-associated plaques. A key role for genetic effects has suggested distribution of lesions and severity of destruction in each individual [2].

Karl Landsteiner discovered the fundamental principles of blood grouping in 1900s [3]. He described the blood groups according to "ABO" blood typing system. Since then, we have been able to categorize individuals according to their blood groups. This relationship of blood groups and dental diseases goes back to 1930, when Ishikawa and Mahajan [4,5] studied the association of ABO blood group with periodontal disease. Kaslick studied the association of aggressive periodontitis and $\mathrm{ABO}$ blood group and found 
significantly less people with blood group $\mathrm{O}$ and more people with blood group B [6].

Various studies have investigated the relationship between blood type and dental caries \& periodontal disease. Individuals with blood group A have lower dental caries incidence as compared to those with other blood groups. The secretion of $\mathrm{ABO}$ antigens into saliva probably inhibits the ability of bacteria to attach to the tooth surface, which may be because these bacteria have surface lectins, used to attach to body surfaces and are often ABO specific. Also, non-secretors have lower levels of immunoglobulin A (IgA) antibodies in their saliva, which may compromise their ability to keep bacterial count low [7]. It has been noted that many individuals with high rates of dental caries have less periodontal disease, and vice versa. The possible mechanism by which individuals of a specific blood group have a lower frequency of periodontal disease could be due to increased levels of antibodies [1].

Limited efforts have been made to investigate the relationship between $\mathrm{ABO}$ blood group and oral disease. Majority of the researchers [8-12] have claimed that different $\mathrm{ABO}$ blood groups constitute an increased risk for the development of oral diseases. Knowledge of the ABO blood groups of patients and their association with the dental diseases is very important, this can help in the development of early diagnosis and treatment strategies.

In today's fast moving world depression is the main causative factor for almost every systemic disease. Dentists seem to be prone to clinical depression because of the variety of sources of stress he/she encounters throughout the professional career [13-16].

Depression may be a consequence of prolonged burnout experience [17]. Little attention has been paid to depression among dental students. The results of studies conducted on clinical study years ranged between 2.8 and $15 \%$, and between 7.4 and $14 \%$ on preclinical years $[18,19,20]$, using different instruments and cut off values to screen for depression. Exploring the relationships between blood groups, oral diseases and depression can help prevention and early diagnosis of various systemic diseases.

Keeping the above mentioned points into mind the present study was undertaken to study the association among different blood groups, depression and oral hygiene of dental students of a private dental institute.

\section{Materials and method}

The present cross-sectional study was conducted among the undergraduate and postgraduate students of a dental college in the department of Public Health Dentistry, Jaipur city. The study design was reviewed and approved by the Ethical Committee of the institute. Informed consent was obtained from the students. They were given prior information about the study procedure, date and timing.

All the students present on the day of examination were included in the study. A total of 315 students participated in the study, out of which 95 and 220 were male and female respectively. The study subjects were divided by undergraduate academic year, Interns and postgraduates. The subjects in first year to final years were 56, 78, 65 and 83 respectively, interns and postgraduates were 13 and 20 respectively.

The study was done in two phases, during the first phase blood samples of all the study subjects were collected with the help of nursing students (nursing college in the same campus) and were sent for analysis of $\mathrm{ABO}$ blood group and $\mathrm{Rh}$ factor in the general pathology and microbiology department of the institute. During the second phase of the study the demographic data (gender, age years of study) were recorded on a proforma, and oral health examination was carried out in the department of public health dentistry.

Dental caries and Oral hygiene status were recorded using DMFT Index [21] (decayed, missing and filled teeth were recorded) and OHI-S index [22] (OHI-S score showing Good, Fair and Poor oral hygiene status) respectively, and the depression score was recorded using the Beck's Depression Inventory (This depression inventory can be self-scored) under the guidance of a senior faculty member.

The data was entered into Microsoft Excel sheet 2007 and subjected to statistical analysis using SPSS ver. 20.0. Chi square test was used for analysis of categorical variable.

\section{Results}

A total of 315 students participated in the study out of which 95 were male and 220 were female. The mean age of the subjects was $21.34+2.30$. (Table I)

The majority of the subjects (41\%) had blood group $\mathrm{B}+$ followed by $\mathrm{O}+(22.9 \%)$ and $\mathrm{A}+(19.7 \%)$ respectively. Very few subjects (2) were in AB- blood group. (Table II)

Table I. Distribution of study subjects according to academic year.

\begin{tabular}{ll}
\hline Academic year & $\mathbf{( N = 3 1 5 ) ( \% )}$ \\
\hline 1st year BDS & $56(17.8)$ \\
\hline 2nd year BDS & $78(24.8)$ \\
\hline 3rd year BDS & $65(20.6)$ \\
\hline final year BDS & $83(26.3)$ \\
\hline Interns & $13(4.1)$ \\
\hline Post graduate students & $20(6.3)$ \\
\hline Total & $315(100.0)$ \\
\hline
\end{tabular}

Table II. Distribution of study subjects according to blood group.

\begin{tabular}{ll}
\hline Blood group & $(\mathbf{N}=\mathbf{3 1 5})(\mathbf{\%})$ \\
\hline $\mathbf{O}-$ & $6(1.9)$ \\
\hline $\mathbf{O}+$ & $72(22.9)$ \\
\hline $\mathbf{A}-$ & $7(2.2)$ \\
\hline $\mathbf{A}+$ & $62(19.7)$ \\
\hline $\mathbf{B}-$ & $10(03.2)$ \\
\hline $\mathbf{B}+$ & $129(41.0)$ \\
\hline $\mathbf{A B}-$ & $2(0.6)$ \\
\hline $\mathbf{A B}+$ & $27(8.6)$ \\
\hline Total & $315(100.0)$ \\
\hline
\end{tabular}


Table III depicts the association between blood group and DMFT score. About half of the subjects (55.23\%) had DMFT score 0 . Among the study subjects with blood group $\mathrm{B}+, 75$ had DMFT score 1 to 8 . Twenty two subjects had DMFT score 22 and one subject had score 8 . Subjects with blood group AB- had lowest number, with only 2 subjects having DMFT score of 1 and 6. On applying chi square test a statistically significant $(\mathrm{p}=0.0)$ result was obtained between the blood groups and the dental caries (DMFT score).

When the blood group and oral hygiene of the study subjects was assessed, it was observed that $80.62 \%$ and $19.37 \%$ of the subjects with blood group $\mathrm{B}+$ had good and fair oral hygiene respectively; while $50 \%$ of the subjects with blood group AB- had good and fair oral hygiene. When chi square test was applied to find the association between oral hygiene index-simplified and blood group, a statistically non significant association was observed $(\mathrm{p}=0.668)$ (Table IV).

When the correlation between blood group and depression score of the study subjects was assessed, it was observed that extreme depression was seen in $17(\mathrm{~B}+$ blood group) subjects. A statistically non significant association was observed between the depression score and blood group of the study subjects $(\mathrm{p}=0.74)($ Table V).

Table III. Association between blood group and DMFT score (\# Chi square test).

\begin{tabular}{|c|c|c|c|c|c|c|c|c|c|c|c|c|}
\hline \multirow[t]{2}{*}{ Blood group } & \multicolumn{9}{|c|}{ DMFT } & \multirow[t]{2}{*}{ Total } & \multirow[t]{2}{*}{$\mathrm{X}^{2 \#}$} & \multirow[t]{2}{*}{ p value } \\
\hline & 00 & 1 & 2 & 3 & 4 & 5 & 6 & 7 & 8 & & & \\
\hline O- & 2 & 2 & 2 & 0 & 0 & 0 & 0 & 0 & 0 & 6 & \multirow{9}{*}{98.207} & \multirow{9}{*}{$0.0^{*}$} \\
\hline $\mathbf{O +}$ & 47 & 10 & 4 & 6 & 2 & 3 & 0 & 0 & 0 & 72 & & \\
\hline A- & 5 & 2 & 0 & 0 & 0 & 0 & 0 & 0 & 0 & 7 & & \\
\hline $\mathbf{A}+$ & 33 & 15 & 7 & 3 & 4 & 0 & 0 & 0 & 0 & 62 & & \\
\hline B- & 2 & 3 & 1 & 3 & 1 & 0 & 0 & 0 & 0 & 10 & & \\
\hline $\mathbf{B}+$ & 73 & 22 & 15 & 5 & 8 & 2 & 1 & 2 & 1 & 129 & & \\
\hline AB- & 0 & 1 & 0 & 0 & 0 & 0 & 1 & 0 & 0 & 2 & & \\
\hline $\mathbf{A B}+$ & 12 & 3 & 6 & 2 & 2 & 1 & 1 & 0 & 0 & 27 & & \\
\hline Total & 174 & 58 & 35 & 19 & 17 & 6 & 3 & 2 & 1 & 315 & & \\
\hline
\end{tabular}

* Highly Significant $(\mathrm{p} \leq 0.00)$

Table IV. Association between oral hygiene index-simplified and blood group (\# Chi square test).

\begin{tabular}{|c|c|c|c|c|c|c|c|c|c|c|c|}
\hline \multirow{2}{*}{$\begin{array}{l}\text { Oral hygiene } \\
\text { index-Simplified } \\
(\mathrm{OHI}-\mathrm{S})\end{array}$} & \multicolumn{8}{|c|}{ Blood group } & \multirow[t]{2}{*}{ Total } & \multirow[t]{2}{*}{$\mathrm{X}^{2 \#}$} & \multirow[t]{2}{*}{ p value } \\
\hline & O- & $\mathbf{O}+$ & A- & $\mathbf{A}+$ & B- & $\mathbf{B}+$ & AB- & $\mathbf{A B}+$ & & & \\
\hline Good & 4 & 55 & 6 & 49 & 6 & 104 & 1 & 19 & 244 & \multirow{3}{*}{4.93} & \multirow{3}{*}{$0.668^{¥}$} \\
\hline Fair & 2 & 17 & 1 & 13 & 4 & 25 & 1 & 8 & 71 & & \\
\hline Total & 6 & 72 & 7 & 62 & 10 & 129 & 2 & 27 & 315 & & \\
\hline
\end{tabular}

$¥$ Non Significant $(\mathrm{p}>0.00)$

Table V. Association between depression score and blood group (\# Chi square test).

\begin{tabular}{|c|c|c|c|c|c|c|c|c|c|}
\hline \multirow{2}{*}{$\begin{array}{l}\text { Blood } \\
\text { Group }\end{array}$} & \multicolumn{6}{|c|}{ Depression score } & \multirow{2}{*}{$\begin{array}{l}\text { Total (number } \\
\text { of subjects) }\end{array}$} & \multirow[t]{2}{*}{$\mathrm{X}^{2 \#}$} & \multirow[t]{2}{*}{ P Value } \\
\hline & $\begin{array}{l}\text { Normal up- } \\
\text { and downs }\end{array}$ & $\begin{array}{l}\text { Mild mood } \\
\text { disturbance }\end{array}$ & $\begin{array}{l}\text { Borderline } \\
\text { clinical } \\
\text { depression }\end{array}$ & $\begin{array}{l}\text { Moderate } \\
\text { depression }\end{array}$ & $\begin{array}{l}\text { Severe } \\
\text { depression }\end{array}$ & $\begin{array}{l}\text { Extreme } \\
\text { Depression }\end{array}$ & & & \\
\hline O- & 0 & 3 & 1 & 1 & 0 & 1 & 6 & \multirow{9}{*}{47.719} & \multirow{9}{*}{$0.74^{¥}$} \\
\hline $\mathbf{O +}$ & 8 & 26 & 16 & 5 & 12 & 5 & 72 & & \\
\hline A- & 0 & 2 & 3 & 0 & 2 & 0 & 7 & & \\
\hline $\mathbf{A +}$ & 7 & 14 & 19 & 9 & 9 & 4 & 62 & & \\
\hline B- & 0 & 7 & 0 & 1 & 0 & 2 & 10 & & \\
\hline $\mathbf{B}+$ & 12 & 39 & 31 & 10 & 20 & 17 & 129 & & \\
\hline AB- & 2 & 0 & 0 & 0 & 0 & 0 & 2 & & \\
\hline $\mathbf{A B}+$ & 3 & 12 & 3 & 3 & 3 & 3 & 27 & & \\
\hline $\begin{array}{l}\text { Total } \\
\text { (number of } \\
\text { subjects) }\end{array}$ & 32 & 103 & 73 & 29 & 46 & 32 & 315 & & \\
\hline
\end{tabular}

$¥$ Non Significant $(\mathrm{p}>0.00)$ 


\section{Discussion}

The purpose of the present study was to assess the association between different blood groups, depression and oral health status of the dental students.

In the present study 315 subjects participated, which is similar to the study conducted by Vivek et al [2] and contrary to the study done by Demir et al. [9] and Singla et al. [23]. In our study the maximum number of the subjects had $\mathrm{B}+(41 \%)$ and $\mathrm{O}+(22.9 \%)$ blood group. These results are similar to the study conducted by Singla et al. [23] $(\mathrm{O}+39.3 \%$ and $\mathrm{B}+24 \%)$ and Mazumdar P et al. [7] $(\mathrm{B}+36.5 \%$ and $\mathrm{O}+28.1 \%)$. While the results are not in agreement with the study conducted by Demir et al. [9] $(\mathrm{O}+30.3 \%$ and $\mathrm{B}+14.3 \%)$ and Humagain et al. [24] $(\mathrm{O}+28.2 \%$ and $\mathrm{B}+25.7 \%)$. The present study revealed that all the study subjects with AB- and B-blood groups had dental caries. Minimum number of dental caries was observed in the subjects with the blood group A-. The results of the present study were supported by the study conducted by Mazumdar et al. [7] and Singla et al. [23], in which the subjects with B blood group had most dental caries but it was contrary to $\mathrm{AB}$ blood group which had lowest dental caries prevalence.

In the present study good oral hygiene was observed in $77.46 \%$ of the study subjects, while $22.53 \%$ of the study subjects had fair oral hygiene; one hundred four subjects had blood group $\mathrm{B}+$ and only one subject of AB- blood group had good oral hygiene. Similar results were observed in a study done by Ali Al Ghamdi (2009) [1] where he observed that blood group B had good and fair oral hygiene; he did not consider the Rh factor of the blood groups. Similarly subjects with B+ blood group also had maximum number of study subjects, 25 with fair oral hygiene and 1 subject of AB- and A- blood group.

When depression score was calculated $40 \%$ of the post graduate and $32.53 \%$ of the final year subjects had severe depression while $38.46 \%$ of interns and $36.92 \%$ of third year subjects had borderline clinical depression. While $55.12 \%$ of second year and $33 \%$ of first year subjects had mild mood disturbance and ups and downs which are considered normal. When depression scores with blood groups were assessed a non significant association was observed $(\mathrm{p}=0.74)$ between the two. These results were found not in agreement with findings of Galan et al. (2013) [25] in which prevalence of depression in the second and fourth years was higher than in the fifth year (interns).

\section{Conclusion}

Dental caries (DMFT score) varies among the different blood groups and this might suggest a positive association between blood groups and the DMFT score. However, there is no effect on the depression level, oral hygiene and the subjects with different blood groups.

\section{References}

1. Ghamdi AST. Al. Association between ABO Blood Groups and Severity of Chronic Periodontitis. JKAU: Med. Sci.2009; 16(3):31-41.

2. Vivek S, Jain J, Simon SP, Battur H, Supreetha S, Haridas R. Association of ABO Blood Group and Rh factor with Periodontal Disease in a Population of Virajpet, Karnataka: A Cross-Sectional Study. J Int Oral Health. 2013;5(4):30-34.

3. Chaudri S. Concise Medical physiology. 2nd ed. Calcutta: National central book agency (P) Ltd; 1993, pp 84-88.

4. Ishikawa I. Host responses in periodontal diseases: a preview. Periodontol 2000. 2007;43:9-13.

5. Mahajan NM, Kohad RM. Association between ABO blood groups and periodontal diseases. JISP. 1998;1:62-63.

6. Kaslick RS, Chasens AI, Tuckman MA, Kaufman B. Investigation of periodontosis with periodontitis: literature survey and findings based on ABO blood groups. J Periodontol. 1971;42:420-427.

7. Mazumdar P, Das UK, Goswami S. Correlation between blood group and dental caries in 20-60 years age group: A study. International Journal of Advanced Research. 2014;2(11):413-424. 8. Arowojolu MO, Dosmu EB, Adingbola TS. The relationship between juvenile and non-juvenile periodontitis, $\mathrm{ABO}$ blood groups and haemoglobin types. Afr J Med Med Sci. 2002;31(3):249-252.

9. Demir T, Tezel A, Orbak R, Eltas A, Kara C, Kavrut F. The effect of $\mathrm{ABO}$ blood types on periodontal status. Eur J Dent. 2007;1(3):139-143.

10. Gawrzewska B. ABO, Rh and MN blood groups systems and $\mathrm{ABH}$ group factors in saliva as related to perirodontal diseases. Czas Stomatol. 1975;28(10):1007-1014.

11. Kaslick RS, West TL, Chasens AI. Association between ABO blood groups, HL-A antigens and periodontal diseases in young adults: a follow-up study. J Periodontol. 1980;51(6):339-342.

12. Pradhan AC, Chawla TN, Samuel KC, Pradhan S. The relationship between periodontal disease and blood groups and secretor status. J Periodontal Res. 1971;6(4):294-300.

13. Rada RE, Johnson-Leong C. Stress, burnout, anxiety and depression among dentists. J Am Dent Assoc. 2004;135:788-794. 14. Ríos-Santos JV, Reyes-Torres M, López-Jiménez A, MorilloVálazquez JM, Bullón P. Burnout and depression among Spanish periodontology practitioners. Med Oral Patol Oral Cir Bucal. 2010;15:e813-e819.

15. Alemany Martínez A, Berini Aytés L, Gay Escoda C. The burnout syndrome and associated personality disturbances. The study in three graduate programs in Dentistry at the University of Barcelona. Med Oral Patol Oral Cir Bucal. 2008;13:E444-E450. 16. Reyes-Torres M, Ríos-Santos JV, López-Jiménez A, HerreroCliment M, Bullón P. Job satisfaction and depression in the Spanish Society of Periodontology and Research (SEPA) members, and their relation to the burnout syndrome. Creation of a structural model. Med Oral Patol Oral Cir Bucal. 2012;17:e821-e824.

17. Salanova M, Schaufeli W, Martinez I, Breso E. How obstacles and facilitators predict academic performance: the mediating role of study burnout and engagement. Anxiety Stress Coping. 2010;23:53-70.

18. Prinz P, Hertrich K, Hirschfelder U, de Zwaan M. Burnout, depression and depersonalisation--psychological factors and coping strategies in dental and medical students. GMS Z Med Ausbild. 2012;29(1):Doc10. doi: 10.3205/zma000780.

19. Newbury-Birch D, Lowry RJ, Kamali F. The changing 
patterns of drinking, illicit drug use, stress, anxiety and depression in dental students in a UK dental school: a longitudinal study. $\mathrm{Br}$ Dent J. 2002;192:646-649.

20. Takayama Y, Miura E, Miura K, Ono S, Ohkubo C. Condition of depressive symptoms among Japanese dental students. Odontology. 2011;99:179-187.

21. Klein H, Palmer CE, Knutson JW. Studies on dental caries. I. Dental status and dental needs of elementary school children. Public Health Rep. 1938;53:751-765.

22. Greene JC, Vermillion Jr. The Simplified Oral Hygiene Index. J Am Dent Assoc. 1964;68:7-13.
23. Singla S, Verma A, Goyal S, Singla I, Shetty A. Correlation of dental caries and blood group in Western Punjab population in India. Indian journal of multidisciplinary dentistry. 2015; 5(2):59-61.

24. Humagain M, Rokaya D. Evaluation of association between the prevalence and severity of periodontal diseases and $\mathrm{ABO}$ blood groups among nepalese adults. Ind J Sci Res Tech. 2014; 2(3):66-70.

25. Galán F, Ríos-Santos JV, Polo J, Rios-Carrasco B, Bullón P. Burnout, depression and suicidal ideation in dental students. Med Oral Patol Oral Cir Bucal. 2014;19(3):e206-e211. 